\title{
Pediocins: The bacteriocins of Pediococci. Sources, production, properties and applications Maria Papagianni* and Sofia Anastasiadou
}

\author{
Address: Department of Hygiene and Technology of Food of Animal Origin, School of Veterinary Medicine, Aristotle University of Thessaloniki, \\ Thessaloniki 54006, Greece \\ Email: Maria Papagianni* - mp2000@vet.auth.gr; Sofia Anastasiadou - mpapagianni@hotmail.com \\ * Corresponding author
}

Published: 8 January 2009

Microbial Cell Factories 2009, 8:3 doi:10.1 186/1475-2859-8-3
Received: II December 2008

Accepted: 8 January 2009

This article is available from: http://www.microbialcellfactories.com/content/8/I/3

(C) 2009 Papagianni and Anastasiadou; licensee BioMed Central Ltd.

This is an Open Access article distributed under the terms of the Creative Commons Attribution License (http://creativecommons.org/licenses/by/2.0), which permits unrestricted use, distribution, and reproduction in any medium, provided the original work is properly cited.

\begin{abstract}
Class Ila bacteriocins from lactic acid bacteria are small, cationic proteins with antilisterial activity. Within this class, the pediocins are those bacteriocins that share a highly conserved hydrophilic and charged $\mathrm{N}$-terminal part harboring the consensus sequence -YGNGV- and a more variable hydrophobic and/or amphiphilic C-terminal part. Several pediocins have been isolated and characterized. Despite the structural similarities, their molecular weight varies, as well as their spectrum of antimicrobial activity. They exhibit important technological properties, e.g. thermostability and retaining of activity at a wide $\mathrm{pH}$ range, which along with the bactericidal action against Gram-positive food spoilage and pathogenic bacteria, make them an important class of biopreservatives. Much new information regarding the pediocins has emerged during the last years. In this review, we summarize and discuss all the available information regarding the sources of pediocins, the characteristics of their biosynthesis and production in fermentation systems, the characteristics of the known pediocin molecules, and their antibacterial action. The advances made by genetic engineering in improving the features of pediocins are also discussed, as well as their perspectives for future applications.
\end{abstract}

\section{Background}

Peptides with antimicrobial properties (AMPs) are produced by eukaryotes and prokaryotes and serve as important components of their defense against microorganisms. Many bacteria are able to synthesize antimicrobial peptides. Those synthesized in the ribosomes, are generally referred to as bacteriocins (antibiotics are not included in the group since they are not ribosomally synthesized). The bacteriocins produced by Gram-negative bacteria are most often large proteins (many are larger that $20 \mathrm{kDa}$ ) and their inhibition spectrum is rather narrow, spanning to closely related species. Colicin $\mathrm{V}$ and the microcins, are exceptions as they are smaller than $10 \mathrm{kDa}$.
Gram-positive bacteria most often produce peptide bacteriocins smaller than $6 \mathrm{kDa}$. They are often cationic, amphiphilic, membrane-permealizing peptides, which in this manner resemble many of the AMPs produced by eukaryotes. They appear, however, to be effective in very low concentrations (often picomolar to nanomolar concentrations), although the action spectra are often narrow at these concentrations [1]. The bacteriocins produced by lactic acid bacteria (LAB) are divided into three main groups: the lantibiotics, which are modified bacteriocins (class I), the nonlantibiotics, which are heat-stable and unmodified (class II), and a group of large heat-labile bacteriocins (class III). Another group, known as class IV, is 
often included in classifications. Bacteriocins of class IV are complex molecules with lipid and carbohydrate moieties.

Most of the known ribosomally synthesized antimicrobial peptides produced by bacteria have been identified and studied during the last 20 years. Those produced by LAB, and in particular the lantibiotics, are the most extensively studied. Characteristics, among which antilisterial activity, increased specificity and effectiveness in very low concentrations, have long attracted the interest of the food sector for applications in food preservation. Nisin, the lantibiotic produced by Lactococcus lactis strains, is undoubtedly the most well-known, studied and characterized bacteriocin and the only one with widespread commercial use in most major food-producer countries. The success of nisin has led many research groups in searches for novel bacteriocin-producer strains and bacteriocins over the last years. This has resulted in a growing range of potential biopreservatives, with most promising the pediocins. These are AMPs produced by Pediococcus spp., which are categorized in the $2^{\text {nd }}$ class of bacteriocins from $\mathrm{LAB}$, the known as "antilisterial" bacteriocins.

The potential applications of bacteriocins from LAB in the food and health care sectors have attracted the strong interest of academia and the industry resulting in an impressive amount of published research on their production, purification, genetics and applications. Since chemical preservatives are being continuously questioned with regard of safety, the use of LAB and their metabolites is generally accepted by consumers as something natural and health promoting. This offers a logical explanation for the non-reducing interest of the food scientists in the particular area and the expanding trend of applications of $\mathrm{LAB}$ in the food industry.

In this review, we will focus on the research and published literature on pediocins. Topics such as producer strains, characteristics of production in fermentation, structure of characterized pediocins, biochemical properties, antimicrobial spectra, and potential applications will be discussed in detail.

\section{The genus Pediococcus}

Pediococcus is a genus of Gram-positive lactic acid bacteria, belonging to the family of Lactobacillacea. The genus Pediococcus consists of the following species: P. acidilactici, $P$. pentosaceus, $P$. damnosus, $P$. parvulus, $P$. inopinatus, $P$. halophilus, $P$. dextrinicus, and $P$. urinaeequi [2]. The often referred to as $P$. cerevisiae, is currently designated as $P$. damnosus, while strains formerly known as $P$. cerevisiae today are distributed among $P$. damnosus, $P$. acidilactici and $P$. pentosaceus [2-5]. Also, the taxonomic status of $P$. halophilus and $P$. urinaeequi remains uncertain $[6,7]$. Pedi- ococcus spp. cells are spherical and arranged in tetrads, however, pairs are not uncommon in liquid cultures. They divide along two planes of symmetry, as do the other lactic acid cocci genera of Tetragenococcus and Aerococcus. They are facultative anaerobes, non motile and non sporulating [8]. The genus is paraphyletic and P. dextrinicus is only distantly related to the other species.

Pediococci are cultivated successfully in rich media [9]. Various species and strains differ in tolerance to oxygen, $\mathrm{pH}$, temperature and $\mathrm{NaCl}$ [5]. They are homofermentative, although carbohydrate assimilation patterns and fermentation may differ among species and strains. Glucose is always fermented to racemic DL-lactate by the EmbdenMeyerhof-Parnas (EMP) pathway [10]. Metabolic end products vary according to the conditions provided.

Among the known Pediococcus strains, P. acidilactici, P. pentosaceus, and $P$. halophilus are mostly associated with food fermentations. P. acidilactici and P. pentosaceus, take place in food fermentations either as indigenous microflora or in starters and both have been used in natural and controlled fermentations of vegetables and sausages $[11,12]$. Since pediococci typically are unable to ferment lactose [2], their applications in milk fermentations are restricted. There are however, a number of reports [13-15] which indicate that non starter and adjunct Pediococcus spp. impart desirable attributes to cheese suggesting that they may be good dairy starters if they possess the ability to utilize the particular sugar [16]. The ability of $P$. acidilactici and $P$. pentosaceus to produce antimicrobial peptides has attracted the interest for the use of either the cultures or their products as protective cultures or biopreservatives, respectively, in many foods. Both $P$. acidilactici and $P$. pentosaceus have also been used in silage fermentation, in the fermentation of dough and fruit juices, while several commercial probiotic feeds containing either species are currently available in the market.

P. halophilus (also known as Tetragenococcus halophila) plays an important role in the fermentation of miso and soy sause [11] and it is known as the soy Pediococcus $[17,18]$. The soy sauce mash or moromi has been the source for isolation of $P$. halophilus strains. The soy pediococci, salt-tolerant and homofermentative lactic acid bacteria, metabolize citrate and malate during lactic acid fermentation of soy sauce brewing. Citrate and malate are the acids that lactic acid bacteria most often encounter in their food environments and in the manufacture of fermented dairy products it is desirable that they are able to metabolize the two acids into especially, acetoin and diacetyl, both regarded as being favourable in enriching the flavours of cheese, butter and other products. Several strains however, have been described as non-citratemetabolizing strains [19]. 
$P$. damnosus occurs in wine and cider and is found in brewery environments. It occurs as primary contaminant in pitching yeast and it is among the most prevalent spoilage microorganisms [20]. P. damnosus is sensitive to bacteriocins nisin of Lactococcus lactis [21] and pediocin AcH of $P$. acidilactici $\mathrm{H}[5]$, while it has been reported to produce a pediocin [22].

The various Pediococcus species exhibit different physiological characteristics which can be used for identification purposes. However, there are always strains within defined species that are different from the type strains. Various genetic tools have been used to discriminate between strains in the genus Pediococcus. These include the use of specific DNA target probes [23-25], ribotyping [2628], total DNA-DNA hybridization [6], 16S rRNA gene sequencing $[28,29]$. Simpson et al. [30] studied the genomic diversity within the genus Pediococcus by randomly amplified polymorphic DNA PCR and pulse-field gel electrophoresis: specific DNA fragments within the NotI and AscI macrorestriction patterns for each of the 33 examined strains from six species, were observed that allowed 27 of the 33 strains to be assigned to their proposed species. Following digestion with AscI, all P. parvulus strains were characterized by two DNA fragments (220 $\mathrm{kb}$ and $700-800 \mathrm{~kb}$ ). The exceptions correlated with those observed with both RAPD PCR primers and included three $P$. damnosus and two $P$. pentosaceus strains that grew at temperatures regarded as non permissive for their proposed strains but not for those with which they grouped.

Strains belonging to the species of $P$. acidilactici and P. pentosaceus have been separated by DNA-DNA homology, $16 \mathrm{~S}$ rRNA, and mol\% G+C in DNA techniques and by immunoassays. Bhunia and Johnson [31] have shown that the ELISA test with the monoclonal antibody Ped 2B2 can be used to differentiate between the two species, an approach that could find wider application in discriminating among closely related species.

Since the subject of this review is the pediocins-bacteriocins produced by Pediococcus spp. - the sections that follow will include information only on the pediocin producers: $P$. acidilactici, P. pentosaceus and P. damnosus.

\section{Pediocins}

The Class II of unmodified bacteriocins is subdivided into the groups of the pediocin-like bacteriocins and the twopeptide bacteriocins. These are generally small $(<5 \mathrm{kDa})$ and unmodified peptides. The pediocin-like bacteriocins (36-48 residues) are produced by many lactic acid bacteria and share a 40-60\% amino acid sequence similarity [1]. The peptides of this group are known as "antilisterian" or "Listeria-active" peptides and they are characterized by a -Y-G-N-G-V-N- terminus. The hydrophilic N- terminal is well conserved. The N-terminal region of all pediocins currently identified contains two cysteines, joined by a disulfide bond, in a motif known as the "pediocin box": -Y-G-N-G-V-X ${ }_{1}-\mathrm{C}-\mathrm{X}_{2}-\mathrm{K} / \mathrm{N}-\mathrm{X}_{3}-\mathrm{X}_{4}-\mathrm{C}-$, with $\mathrm{X}_{1-4}$ representing polar uncharged or charged residues.

Pediocins are synthesized with a leader peptide attached which is removed by proteolytic processing, usually after a double glycine residue. Processing of pediocins has been reviewed for pediocin AcH and pediocin PA-1 [5]. Studies with pediocin $\mathrm{AcH}$ revealed that at the translation level it is synthesized as a biologically inactive peptide with 66 amino acid residues. It then undergoes a posttranslational modification, which includes the removal of a leader fragment of 18 amino acids from the N-terminal, to produce a 44 amino acid peptide that is biologically active [32]. Posttranslational modification is enzyme dependent and occurs at low $\mathrm{pH}$ at which activation of processing enzymes takes place [5,33]. Studies by other researchers $[34,35]$ have shown that pediocin PA-1 undergoes a similar posttranslational processing.

\section{Pediocin producer strains \\ Pediococcus acidilactici}

$P$. acidilactici strains are found in plants and milk. The optimum temperature for growth is $40^{\circ} \mathrm{C}$. It is able however to grow at $50^{\circ} \mathrm{C}$. A pH of 6.0 is regarded as the optimum for starting cultivation. During growth, the $\mathrm{pH}$ falls to levels as low as 3.6 [36]. Most strains ferment glucose, ribose, xylose, fructose and galactose to DL-lactate. A few strains are able to ferment lactose, sucrose and maltose [5]. Some strains have heme-requiring catalase, while all strains hydrolize arginine. Some strains have been found to produce pediocins. Pediocin optimum production conditions however, could differ from the optimum growth conditions [36]. P. acidilactici is used worldwide in fermentations of vegetables (e.g. sauerkraut), and meatbased products (e.g. dry sausages). Some vancomycinresistant $P$. acidilactici strains have been found to be the responsible bacteria for repeated septicemia cases [37].

\section{Pediococcus pentosaceus}

The species share many characteristics in common with $P$. acidilactici, except a few: $P$. pentosaceus do not grow at $50^{\circ} \mathrm{C}$, it withstands salt concentrations as high as $10 \%$, while $P$. acidilactici do not, and the optimum temperature for growth is between 28 and $35^{\circ} \mathrm{C}$. Most strains ferment glucose, ribose, galactose, arabinose, and fructose to DLlactate. A few strains are able to ferment lactose, and xylose [5] and some strains are known to possess catalase activity $[38,39]$. $P$. pentosaceus have been implicated in a wide variety of fermentation processes, such as in the brewing industry and as starter cultures in sausage fermentations [40]. They also play important roles in silage fermentations and they are present in dairy products, 
vegetables and plant-based products (e.g. ripened cheese) $[5,40,41]$. Hexoses are metabolized by $P$. pentosaceus via the EMP (glycolytic) pathway, however, the oxidative metabolism, through aerobic reactions, and an active flavoprotein system were early investigated and presented by Dobrogosz and Stone [38]. Selective P. pentosaceus strains produce pediocins and have been the focus of much research with regard to food preservation. $P$. pentosaceus, appears in the literature to be more investigated than $P$. acidilactici from the physiology and genetics point of view. The full genome of $P$. pentosaceus ATCC 25745 has been sequenced $[42,43]$ and is made up of $1,832,387$ nucleotides organized in a circular manner. The genome has 1,755 protein encoding genes and 72 RNA genes and a $37.4 \%$ GC content. Plasmids associated with metabolism and bacteriocin synthesis have been isolated and characterized and a large number of transporter proteins are known today [44]. P. pentosaceus has been identified as an opportunistic pathogen $[45,46]$, while it is considered as probiotic bacterium and an increasing number of probiotic products include it among other lactic acid bacteria.

\section{Pediococcus damnosus}

P. damnosus is phylogenetically distant from $P$. acidilactici and $P$. pentosaceus [47]. It does not grow at $35^{\circ} \mathrm{C}$, the optimum temperature of $P$. acidilactici and $P$. pentosaceus, while its optimum temperature for growth is $22^{\circ} \mathrm{C}$. The optimum $\mathrm{pH}$ for growth is 5.5. It does not grow at $4 \%$ $\mathrm{NaCl}$, does not hydrolize arginine, arabinose, xylose, and lactose. Most strains ferment glucose, sucrose and galactose homofermentatively, and only some strains metabolize maltose and sucrose. As a beer and wine spoilage bacterium, has attracted research interest and recent publications report on the genetics [48-50], exopolysaccharide production [51] and bacteriocin production by $P$. damnosus [52-54].

\section{Growth and metabolism of pediocin producers Pediococcus spp \\ Growth conditions}

The above described species are chemoorganotrophs. They require most amino acids and vitamins $\mathrm{B}$, while $P$. acidilactici and $P$. pentosaceus require folic and and rivoflavin, respectively [9]. These two species do not have a growth requirement for $\mathrm{NaCl}$ [5]. They grow however, in media with $4 \% \mathrm{NaCl}$, while $P$. halophilus has a growth requirement for $\mathrm{NaCl}>5 \%$. Both $P$. acidilactici and $P$. pentosaceus require traces of $\mathrm{Mn}$ for growth [55].

Although categorized as facultative anaerobes or microaerophilic bacteria, both $P$. acidilactici and $P$. pentosaceus, grow rapidly aerobically and $P$. halophilus grows better aerobically [5]. Studies on growth and metabolism of P. acidilactici NRRL B 5627 performed in a stirred tank bioreactor under various dissolved oxygen tension levels
(DOT) [36], show that aerobic, compared to semi-aerobic (60\% DOT) and anaerobic, conditions led to higher biomass and lactate production levels and to lower pediocin levels. Similar results were obtained by the same group of Anastasiadou et al. [56] for the pediocin producer $P$. pentosaceus Mees 1934.

Information for $P$. acidilactici and $P$. pentosaceus on growth pHs and temperatures, as well as the ability to ferment various sugars has been given by Mundt et al. [57], Garvie [2] and Ray et al. [5]. Most strains are able to ferment glucose, fructose, galactose, mannose, cellobiose, arabinose, ribose, salicin, amygdalin, esculin, but not ferment sorbose, melibiose, inulin, starch, dextrin and sugar alcohols. Fermentation of other carbohydrates is strain dependent. Glucose has been found to have an inhibitory effect on growth of $P$. acidilactici cultures [58]. As mentioned earlier, glucose and other hexoses are metabolized by the EMP pathway. An active phosphoenolopyruvate:phosphotransferase system (PEP:PTS) is involved in the transfer of monosaccharides and data for a large number of transporter enzymes have been generated by genomic research and reported recently $[43,44]$. General PTS and sugar specific PTS enzymes of $P$. pentosaceus ATCC 25745 are known today. Information, however, on specific pathways and in depth research on sugar metabolism and transport mechanisms are still missing from the literature.

In general, there is great strain variation in the ability of $P$. acidilactici and $P$. pentosaceus to ferment carbohydrates such as lactose, sucrose, trealose, rhamnose and others [57]. Inability to ferment or low fermentation rates however, can be improved by genetic engineering strategies. This option could provide solutions to problems in the dairy industry. For example, pediococci (exceptions exist) are unable to ferment lactose but the development of lactose-positive $P$. acidilactici and $P$. pentosaceus, could be useful in replacement of cocci such as Streptococcus thermophilus in Italian starter blends [16]. Since these bacteria grow at $45^{\circ} \mathrm{C}$ and each has a long history of safe consumption in human food, construction of $\mathrm{Lac}^{+}$ transformants would provide a solution to increased incidences of bacteriophage attacks on $S$. thermophilus. $\mathrm{Lac}^{+} P$. acidilactici and $P$. pentosaceus strains were constructed by transformation with the naturally occurring $35-\mathrm{kb}$ L. lactis lactose plasmid, pPN-1, by Caldwell at et. [16]. The transformants were investigated for stability of the $\mathrm{Lac}^{+}$phenotype, the ability to acidify milk, and other important dairy properties. Results indicated that $\mathrm{Lac}^{+}$pediococci have potential as replacement cocci for $S$. thermophilus in starter cultures. The development of gene transfer systems for pediococci has been reported in some cases [16,59-61] and the uptake characteristics of genetically engineered pediococci for lactose and galactose have been investigated [61]. 
$P$. pentosaceus strains that possess a pseudocatalase system were found to be more efficient to glucose conversion to pyruvate under aerobic conditions [5]. The glycerol oxidizing system is inducible. A study of the end products of aerobic glycerol metabolism showed that glycerol was oxidized to the pyruvate level, producing lactate, acetate, acetoin and $\mathrm{CO}_{2}$ in a molar ratio of approximately 1:1:1:3 [38]. Acetoin can then be converted to diacetyl.

The lactate oxidation system of $P$. pentosaceus is inducible and helps the cells to derive energy from the oxidation of lactate to acetate [5]. Under aerobic conditions, L-(+)-lactate is oxidized to $\mathrm{CO}_{2}$ and acetate in equimolar amounts, while under anaerobic conditions, conversion of L-(+)lactate to D-(-)-lactate takes place without production of acetate. Lactate oxidation by pediococci and the production of acetate and $\mathrm{CO}_{2}$ may contribute to the development of distinctive flavour and ripening of the cheddar cheese [5].

Citrate metabolism is inducible in the pediococci. Citrate metabolism has been studied in several strains of soy pediococci by Kanbe and Uchida [19]. It was observed that citrate-negative strains were missing the inducible citrate lyase [citrate (pro-3S)-lyase; EC 4.1.3.6], and pathways of citrate degradation in P. halophilus differed largely from those of other lactic acid bacteria. The main products from citrate were acetate and formate and $P$. halophilus did not produce acetoin or diacetyl. Formate production from citrate was greatly influenced (reduced) in the presence of glucose in the substrate.

$P$. pentosaceus possesses an inducible system for the metabolism of phenolic acids. The microorganism was found to display a substrate-inducible phenolic acid decarboxylase (PAD) activity on p-coumaric acid [62]. Barthelmebs et al. [62] showed that citrate metabolism is encoded by an autoregulated bicistronic operon which involves a new class of negative transcriptional regulator.

Pediococci do not produce extracellular proteases. Studies have shown however $[13,14]$, that they have intracellular proteases, dipeptidases, and amino peptidases. The levels of the intracellular protein- and peptide-hydrolyzing enzymes may differ greatly with strains [5]. Pediococci probably do not produce extracellular lipases. They may contain lipases intracellularly, as was shown for $P$. pentosaceus but not for $P$. acidilactici [13]. The intracellular enzymes of pediococci have important roles in cheese ripening processes. The involvement of various intracellular enzymes, such as N-acetyl-muramidases, N-acetyl-glucosaminidases, l-alanine amidase and endopeptidases (peptidoglycan hydrolases) in the complex process of autolysis, that is important in fermentation processes, have only recently been studied with $P$. acidilactici and $P$. pentosaceus by Mora et al. [63]. The importance of autolysis of lactic acid bacteria in cheese ripening is well known and autolytic enzymes have been detected and characterized in many cases. Mora et al. [63] evaluated the autolytic phenotype in $P$. acidilactici and $P$. pentosaceus strains isolated from vegetable, meat and dairy sources. Peptidoglycan hydrolases of Pediococcus spp. were active in high salt concentrations and at different $\mathrm{pHs}$, suggesting a potential role in salted meat and vegetable fermented products and in cheese ripening conditions when the $\mathrm{pH}$ is low and salt concentration is increasing. A strong effect of pediocin AcH/PA-1 on the level and rate of autolysis was identified with pediocin-sensitive strains.

\section{Conditions for pediocin production \\ Growth conditions}

Pediocin production is greatly influenced by nutritional parameters, temperature, $\mathrm{pH}$ (initial and terminal $\mathrm{pHs}$ of fermentation broth), and aeration levels. Pediocin AcH, produced by $P$. acidilactici $\mathrm{H}$, is an extensively studied and well-known pediocin $[5,32,33,55]$. The factors influencing the production of pediocin $\mathrm{AcH}$ have been reviewed by Ray $[5,64]$. A relatively simple broth (TGE) that contain only trypticase or tryptone, $1 \%$ glucose, $1 \%$ yeast extract, $1 \%$ Tween $80,0.2 \% \mathrm{Mn}^{2+}$, at initial $\mathrm{pH}$ of 6.5 resulted in higher pediocin production levels than MRS broth. Increase of trypticase, glucose, yeast extract to $2 \%$, increased the yield by about a 10\%. Production was highest with glucose, followed by sucrose, xylose, and galactose. Pediocin was not produced on arabinose, trehalose and raffinose, while growth and lactate production were very low with these carbohydrates.

Anastasiadou et al. [65] studied the influence of various nutritional papameters on pediocin production by $P$. acidilactici (pediocin SA-1, [36]) on a per cell basis. The study involved a direct plate bioassay procedure for rapid and quantifiable assessment of the carbon source and various salts. Solid-state cultivation of the microorganism was done on MRS-based media over 3- and 6-hours incubation periods. Glucose, sucrose, fructose, galactose and glycerol were evaluated. Glucose was found to be the optimal carbon source while glycerol exhibited the most suppressive effect. With glucose as the carbon source, addition of various salts in amounts used in liquid media commonly applied in the cultivation of pediococci, was assessed with respect to pediocin production per cell. Incorporation of $\mathrm{NH}_{4} \mathrm{PO}_{4}, \mathrm{CaCl}_{2}, \mathrm{KH}_{2} \mathrm{PO}_{4}$ into the medium resulted in an impressive suppression of pediocin production. Addition of $\mathrm{MnSO}_{4} \cdot \mathrm{H}_{2} \mathrm{O}$ resulted in a significant increase in pediocin yield especially in the 6hours assay. The direct plate assay proved to be a good pilot assay prior to conducting more intensive kinetic analysis in liquid cultivation. 
Growth and metabolism of pediocin SA-1 producer P. acidilactici NRRL B5627 were studied under different aeration conditions in a stirred tank bioreactor using MRS broth [36]. Anaerobic cultivation produced very small amounts of pediocin. Fully aerobic conditions were again unfavourable for pediocin production. Dissolved oxygen tension maintained at $60 \%$ of saturation (semi-aerobic conditions) gave the highest pediocin concentration. The results pointed to a direct effect of dissolved oxygen on pediocin production with no correlative increase of biomass. This suggests that pediocin production is associated with an oxidative metabolic pathway. Semi-aerobic conditions were again the most favourable for pediocin SM-1 production by $P$. pentosaceus [56] with almost 4 -fold higher pediocin yields compared to those obtained with other conditions. Although production of many bacteriocins produced by lactic acid bacteria has been studied under anaerobic conditions, there are certain cases like e.g. nisin $[66,67]$ or amylovorin [68] in which an oxygenenriched atmosphere enhanced production considerably.

Apart from the two studies by Anastasiadou et al. [36,56], literature information relative to pediocins and aeration levels applied during cultivation of the pediococci is, to the best of our knowledge, non existing. Most published studies have been carried out in flasks, without agitation and this applies also, to many other bacteriocins by LAB, with the exception of nisin. This may be due to a general perception of an anaerobic requirement of the LAB. Although anaerobic conditions could be the case for growth and lactate production, several studies on bacteriocins have made it clear that there is an oxygen requirement for successful production. Reliable studies (with cultivation performed in the controlled environment of bioreactors) include: the study by Cabo et al. [66], who reported that nisin A production from $L$. lactis at the maximum biomass point quadrupled when the oxygen saturation percentage increased from 50 to $100 \%$; the work of Amiali et al. [67] with nisin $Z$, in which a requirement for $60 \%$ DOT was identified for increased production; the work of de Vuyst et al. [68] who reported on the oxygen demand for amylovorin biosyntheis from Lactobacillus amylovorus and pointed out the stimulation of bacteriocin production with primary metabolite kinetics under oxygen-enriched, and otherwise unfavourable for growth, conditions.

The optimum temperature for production of pediocin AcH from $P$. acidilactici $\mathrm{H}$ is $30^{\circ} \mathrm{C}$ [5]. Production of pediocin SA-1 from the strain P. acidilactici NRRL B5627 was also at $30^{\circ} \mathrm{C}$ [36]. A higher temperature was selected as the optimum for pediocin production for $P$. acidilactici $\mathrm{F}$ (a sausage isolate) [69]. Production of pediocins from $P$. pentosaceus strains was at $37^{\circ} \mathrm{C}$ for $P$. pentosaceus ACCEL [70], and P. pentosaceus L and S (isolated from pork meat)
[71], $35^{\circ} \mathrm{C}$ for $P$. pentosaceus Pep1 (isolated from sausages) $[72], 30^{\circ} \mathrm{C}$ for $P$. pentosaceus ST18 (isolated from boza drink) [73] and P. pentosaceus SM-1 (isolated from pork sausage) [56]. Pediocin PD-1 from Pediococcus damnosus NCFB1832 [54] is produced at $30^{\circ} \mathrm{C}$.

In all published cases of pediocin production, culture $\mathrm{pH}$ was initially between 6.0 and 6.5. Then, it declines steadily to reach a value of 3.7 to 3.5 within approximately 25 hours. Large amounts of pediocin are secreted in the fermentation broth which is of significantly lower $\mathrm{pH}$ since the onset of fermentation and contains the produced in the meantime lactate $[5,33-36,54]$. The particular conditions are required for the secretion of active pediocin molecules, since posttranslational processing of the initially produced prepediocin takes place only at low $\mathrm{pH}$ at which the responsible enzymes are active [5]. The $\mathrm{pH}$ decline rate and the final $\mathrm{pH}$ reached in the cultures appear to be critical factors in pediocin production. It has been shown for pediocins produced by $P$. acidilactici that production displays primary metabolite kinetics depending on the $\mathrm{pH}$ decline rate [5,74-76].

\section{Production systems}

In general, pediocin production displays primary metabolite kinetics with the rate of production paralleled the growth rate $[5,36,56,58,74-76]$. Pediocin AcH from P. acidilactici $\mathrm{H}$, was detected in the fermentation broth in much higher amounts after the culture $\mathrm{pH}$ had reached 4.0 and growth entered the late exponential phase. Even after the cells had reached the stationary phase (18 hours), considerable amounts of pediocin were produced [5]. Anastasiadou et al. [36] presented kinetic studies of production of pediocin SA-1 from $P$. acidilactici and pediocin SM-1 from P. pentosaceus [56] at different dissolved oxygen levels. Under semi aerobic conditions, that supported the highest specific pediocin production rates, specific production rates followed the specific growth rates and production of both pediocins followed the trend of biomass production. In both cases, production ceased once the stationary phase of growth was reached. Maximum pediocin SA-1 levels were detected at 14 hours (160 AU/ $\mathrm{ml}$ ) and remained stable until 28 hours to decrease steadily beyond that point ( $127 \mathrm{AU} / \mathrm{ml}$ at 52 hours).

Pediocin production was mostly studied in batch culture and with synthetic media. Complex media have been applied in the studies of: Vazquez et al. [58] who used a waste medium for the production of pediocin from P. acidilactici NRRL B5627; Guerra and Pastrana [74], who cultivated $P$. acidilactici NRRL B5627 in whey; Vazquez et al. [77], who cultivated the same Pediococcus strain using waste protein sources from octopus; Nel et al. [78], who cultivated $P$. damnosus in acidic grape broth; Guerra and Pastrana [79], who used mussel-processing waste supple- 
mented with glucose and five nitrogen sources; Vazquez et al. [80], who used peptones from autohydrolysed fish viscera; Guerra et al. $[81,82]$, who cultivated $P$. acidilactici on whey and mussel-processing wastes in fed-batch culture.

Guerra et al. [81,82] reported increased pediocin yields, compared with batch fermentation, in fed-batch cultures with re-alkalization cycles. While growth was dependent on pH change, nitrogen and phosphorus availability and product inhibition (lactate, ethanol and butane-2,3-diol), pediocin production was dependent on both growth and the final $\mathrm{pH}$ reached in each re-alkalization period. The authors described in detail the time-courses of various fermentation parameters, e.g. biomass production, nutrient assimilation, pediocin activity and by-product formation and used the obtained data to construct mathematical models. Models that describe biomass and pediocin production were therefore presented for fed-batch cultures on whey and mussel-processing wastes. The developed models offered a better fit than the logistic or the LuedekingPiret model and can be used to design feeding strategies for enhancing and controlling fed-batch pediocin production.

In a most recent publication, Guerra et al. [83] proceeded in modelling of the stress induced biphasic growth and pediocin production by $P$. acidilactici NRRL B5627 in realkalized fed-batch cultures. Using again whey or mussel processing wastes as substrates and employing the re-alkalization strategy, the authors observed and described a shift from homolactic to mixed acid metabolism and biphasic growth kinetics, which was attributed to a biphasic nitrogen metabolism. An unstructured mathematical model, based on the two phases on nitrogen consumption, was developed and expressed in terms of biomass, product accumulation and substrate utilization.

Pediocin production in continuous culture was reported by Cho et al. [84]. The authors presented a complex bioprocessing strategy for pediocin production involving continuous culture of an immobilized culture of $P$. acidilactici [85], carried out in a bioreactor packed with a fibrous matrix. Cell immobilization in the fibrous matrix was attained by natural attachment to fibres surface and entrapment in the void volume within the matrix. About $94 \%$ of cells were immobilized, the remaining remained suspended. Kinetics of fermentation and production of pediocin were investigated in dilution rates ranging from 0.63 /day to 1.58 /day and at $\mathrm{pH}$ values between 4.0 and 5.5. Maximum bacteriocin activity of $6400 \mathrm{AU} / \mathrm{ml}$ was obtained at dilution rate of at least 1.19/day, at pH controlled at 4.5. The system was operated for 3 months without contamination and clogging, or degeneration of the culture, exhibiting therefore very good long-term stability. The produced pediocin, designated as pediocin $\mathrm{PO} 2$, is a plasmid-encoded peptide with a molecular mass of approximately $4.6 \mathrm{kDa}$.

The effects of different dilution rates and $\mathrm{pHs}$ on pediocin 5 production by $P$. acidilactici UL5 were evaluated in continuous cultures of free and immobilized cells by Huang et al. [86]. A pH decrease from 7.0 to 5.0 led to a large increase in pediocin production (from 128 to $2048 \mathrm{AU} /$ $\mathrm{ml}$ ), at a dilution rate of $0.31 / \mathrm{h}$ in free cell cultures. The $\mathrm{pH}$ effect was not pronounced in immobilized cultures. At the optimum $\mathrm{pH}$ of 5.0, the dilution rate greatly influenced pediocin 5 activity in both free and immobilized cultures. Pediocin 5 production during continuous free cell culture decreased with time for all dilution rates tested, except $0.31 / \mathrm{h}$, and average activity over $144 \mathrm{~h}$ cultures reached a maximal value of $4915 \mathrm{AU} / \mathrm{ml}$ at a dilution rate of $0.26 / \mathrm{h}$. In immobilized culture, production was stable with time and increased with the dilution rate from 256 to $1024 \mathrm{AU} / \mathrm{ml}$, in the range of 0.47 to $2.28 / \mathrm{h}$.

From the above two works on pediocin production in continuous culture, it can be concluded that immobilized cultures offer the desired stability of fermentation for long periods but it cannot be concluded that increased overall productivity in such systems is secured. Unfortunately, the literature on the subject seems to be very limited. Recently, Naghmouchi et al. [87] reported the use of immobilized $P$. acidilactici UL5 cells in repeated-cycle batch cultures for pediocin PA-1 production. Cells were immobilized in locust bean gum gel beads and cultivated in MRS, supplemented with $1 \%$ glucose and whey permeate. The described system was stable and resulted in higher pediocin production levels and volumetric productivity at the end of 0.75- and 2-hour incubation cycles, compared with those of free cell cultures (productivity for pediocin: 5461 and $2048 \mathrm{AU} / \mathrm{ml} / \mathrm{h}$, for immobilized and free cells, respectively).

Pediocin production by $P$. acidilactici NRRL B5627 has also been investigated in solid-state fermentation. Vazquez Alvararez et al. [88] compared production characteristics in submerged fermentation and solid-state culture, carried out in polyurethane foam particles soaked in MRS or waste media (mussel processing waste) with various supplements. For the solid-state analysis, the cultures were treated by successive compression and refilling of tubular minireactors equipped with a piston, without the need for reinoculation. The method was found to be simple, easily controllable and reproducible. Culture productivity was maintained stable for long periods and yields were found to be superior compared to those from submerged culture. 


\section{Characteristics of pediocins \\ Plasmid-associated production}

Most Class IIa bacteriocin genes are plasmid located [89]. Graham and Mc Cay [90] were the first who reported that in $P$. pentosaceus FBB63, a plasmid of $15.7 \mathrm{~kb}$ is responsible for the pediocin phenotype. Association of plasmids of 19.4 and $8.3 \mathrm{~kb}$ in other $P$. pentosaceus strains was also reported by Daescel and Klaenhammer [91] and Hoover at al. [92], respectively.

In $P$. acidilactici, a relationship has early been reported between plasmid-associated bacteriocin production and carbohydrate fermentation patterns [5,59,92-94]. Although in various studies different plasmids are reported, e.g. pSMB 74, pSRQ 11, pPR 72, these plasmids are most likely the same [5], as the same molecule is pediocin AcH and pediocin PA-1, denoted today as pediocin AcH/PA-1 [5,25]. Applying a multilocus typing approach, Mora et al. [25] studied the genomic subpopulations within $P$. acidilactici (a wide selection of different environments of isolation of $P$. acidilactici was considered) and the relationship between pediocin AcH/PA-1 producing and non-producing strains and observed that three of the seven genotypes detected, showed relationships with pediocin AcH/PA-1 production and carbohydrate fermentation patterns. All pediocin-producing and sucrose-positive strains were grouped in genotype VII, melibiose-, sucrose- and raffinose-positive strains in genotype VI, and the arabinose-positive strains in genotype V. Plasmid profiles of $P$. acidilactici strains and plasmid-linked carbohydrate fermentation traits are given by Ray [5].

The class IIa bacteriocin genes are most often arranged in one or a few operons, and their organization has been reviewed by Ennahar et al. [95]. In the case of pediocin $\mathrm{AcH} / \mathrm{PA}-1$ the four genes needed for bacteriocin production and secretion are located in one operon [89]. The four genes are 1) the structural bacteriocin gene, encoding a prebacteriocin; 2) the immunity gene, encoding an immunity protein that protects the bacteriocin producer from its own bacteriocin; 3) the gene encoding the $\mathrm{ABC}$ transporter for secretion; and 4) a gene encoding a complementary protein of unknown function. The way these genes are organized in operons has been discussed in the review by Ennahar et al. [95].

\section{Characteristics of pediocin molecules}

The structure, as well as the structure-function relationship, of class IIa bacteriocins has been the subject of extensive research and has been most recently reviewed by Drider at al. [89]. Belonging to this class, pediocins are cationic peptides with similar primary structures. They contain two structural regions, a highly conserved N-terminal region, that harbors the consensus motif -YGNGV, and a less conserved C-terminal region (residues 18 and on). The conserved -YGNGV- sequence was proposed initially as being responsible for the antilisterial activity of class IIa bacteriocins. Altering specifically residues within the motif resulted in dramatic loss of the activity: the activity of pediocin AcH/PA-1 was dramatically reduced by the Asn5-to-Lys mutation within the motif [96] and similarly the activity of carnobacteriocin B2 was reduced by replacing the Tyr3 with Phe [97]. More recent research however, indicated that some alterations with the YGNGV- sequence can be tolerated [89].

The positively charged residues in class IIa bacteriocins are located mostly in the hydrophilic $\mathrm{N}$-terminal region. It has been shown for pediocin AcH/PA-1 that electrostatic interactions and not the -YGNGV- motif, govern the binding of the pediocin and its fragments to phospholipids vesicles [98]. Lys11 and His12, that are part of the cationic patch in the $\mathrm{N}$-terminal $\beta$-sheet-like region of pediocin $\mathrm{AcH} / \mathrm{PA}-1$, are of special importance for the electrostatic interactions and subsequent mutagenesis studies, in which charged residues in pediocin AcH/PA-1, and in sakacin P (another class IIa bacteriocin), were replaced by neutral residues confirmed earlier research $[96,99,100]$.

The C-terminal region is important in determining the target cell specificity for class IIa bacteriocins [89]. This has been shown by combining $\mathrm{N}$ - and $\mathrm{C}$-terminal regions from different class IIa bacteriocins (hybrid bacteriocins), which displayed target cell specificities similar to the the bacteriocins from which the C-terminal was derived [101]. Also, research carried out with pediocin AcH/PA-1 showed that by cleaving the area from residue 20 to residue 34 , the bactericidal activity of the pediocin was inhibited [102]. This is an indication of a role for the Cterminal in recoginition of target cells.

Pediocin AcH/PA-1 from P. acidilactici PAC1.0 is the bestknown pediocin so far. Its molecular weight is $16.5 \mathrm{kDa}$ and it is plasmid-encoded by a 6.2 magadalton plasmid [93]. Other isolated and characterized pediocins from $P$. acidilactici spp. are: pediocin L50 from $P$. acidilactici L50, isolated from Spanish sausage, with M.W. of about 5.25 $\mathrm{kDa}$ [103]; pediocin AcM from P. acidilactici M, isolated from sausage, with M.W. of about $4.618 \mathrm{kDa}$ [104]; pediocin F from $P$. acidilactici $\mathrm{F}$, isolated from sausage, with M.W. of $4.46 \mathrm{kDa}$ [69]; pediocin SA-1 from $P$. acidilactici NRLL B5627, with M.W. of $3.66 \mathrm{kDa}$ [36]; and others with similar M.W. such as pediocin SJ-1 and pediocin N5p from $P$. acidilactici $[105,106]$.

Isolated and characterized pediocins from $P$. pentosaceus spp. are: the designated as pentocins $\mathrm{L}$ and $\mathrm{S}$ from $P$. pentosaceus strains $\mathrm{L}$ and $\mathrm{S}$ isolated from pork meat, with M.W. of about 27 and $25 \mathrm{kDa}$, respectively [71]; a pediocin of $17.5 \mathrm{kDa}$ M.W. produced by P. pentosaceus ACCEL, 
isolated from meat [70]; a two-peptide bacteriocin, pediocin ST18 from $P$. pentosaceus ST18, isolated from boza [73]; a $5 \mathrm{kDa}$ pediocin from $P$. pentosaceus $\mathrm{K} 23-2$, isolated from Kimchi (a traditional Korean fermented vegetable) [107]; and the pediocin SM-1, a $5.37 \mathrm{kDa}$ bacteriocin produced by $P$. pentosaceus SM-1, isolated from a Greek dry sausage [56].

Pediocin PD-1, with a M.W. of approximately $2.9 \mathrm{kDa}$ is the only known pediocin that is produced by $P$. damnosus. It has been purified, characterized as molecule and studied with respect of its biochemical properties by Green et al. [22] and Bauer et al. [54].

\section{Antibacterial spectrum}

In general, class IIa bacteriocins have a rather narrow spectrum of activity [89]. All class IIa bacteriocins are described as being active against Listeria. They are also active against some other Gram-positive pathogenic bacteria, such as Clostridium spp., and Enterococcus spp. Information on the spectra of antimicrobial activity is given for all isolated pediocins, however it is difficult to compare their potencies. Practical difficulties may come from the different ranges of indicators used or the different assays used for assessment of antimicrobial activity. Comparisons however, have made in some cases. Eijsink et al. [108] measured the activities of different bacteriocins, purified to homogeneity, against a large array of indicator strains. L. monocytogenes was among the most sensitive indicator microorganisms for the four bacteriocins examined. Pediocin AcH/PA-1 and enterocin A inhibited more strains than sakacin P and curvacin A. An extra C-terminal disulfide bridge was hypothesized as the responsible factor for the increased potency. Later, Fimland et al. [109] confirmed that in pediocin-like bacteriocins, the extra Cterminal disulfide bridge contributes to widening the antibacterial spectrum as well as to improving their potency at elevated temperatures.

The antimicrobial activity of pediocin AcH/PA-1 has been studied by Henderson et al. [34] and a list of strains inhibited by the pediocin was given. Elegado et al. [104] compared the antimicrobial activity spectrum of pediocin AcM, produced by $P$. acidilactici $\mathrm{M}$, with that of pediocin AcH/PA-1. Pediocin AcM inhibited a large number of test bacteria including many species in the genera of Lactococcus, Lactobacillus, Pediococcus, Leuconostoc and Enterococcus, wider than that of the purified pediocin $\mathrm{AcH} / \mathrm{PA}-1$. It was very interesting that both pediocins, AcM and AcH/PA-1, inhibited the Gram-negative Aeromonas hydrophila. A later study [110] however, reported that pediocin AcH molecule did not adsorb onto A. hydrophila. Elegado et al. [104] commented that the produced halo in A. hydrophila may have been caused by either pediocin-resistant cells, or recovered cells after sublethal injury, or the inhibitory effect might have not been due to sole effect of the pediocin.

Next to pediocin AcH/PA-1, the pediocin produced by $P$. acidilactici NRRL B 5627 strain is another well-investigated pediocin with respect to its antimicrobial spectrum and conditions of production. Its molecule, however, has only recently been isolated and characterized by Anastasiadou et al. [36] and the pediocin has been designated as pediocin SA-1. Pediocin SA-1 is inhibitory to several food spoilage bacteria and food-borne pathogens. Table 1 gives the actimicrobial activity, in three degrees of sensitivity, of the purified pediocin SA-1 against a range of important for the food sector bacteria. It is not active against Salmonella spp., but compared with pediocin PD-1 (according to data given by Green et al. [22]) by $P$. damnosus, pediocin SA-1 appears to be significantly more effective against Listeria spp. Pediocin SA-1 exhibits intermediate inhibitory activity against other $P$. acidilactici strains and the phylogenetically close $P$. pentosaceus, unlike pediocin PD-1 by $P$. damnosus which showed no activity against these species [22] and small inhibitory activity against known bacteriocin producers Lactobacillus sakei CECT 906T, Lb. plantarum CECT 220, L. lactis ATCC 11454. Pediocin SA-1 was found to be very effective against the anaerobic Clostridium sporogenes and C. thiaminolyticum.

Another recently isolated and characterized pediocin, the pediocin SM-1 from P. pentosaceus SM-1 (a Mees 1934 strain) studied by the same group of researchers as pediocin PA-1[56] and their spectra of activities were compared using the same set of indicator microorganisms. Pediocin SM-1 was found also to be very effective against $L$. monocytogenes and L. inocua, as well as against the anaerobic C. sporogenes and C. thiaminolyticum. A smaller degree of activity was shown against several lactic acid bacteria species, among which Pediococcus spp. Compared with pediocin SA-1, it appears to be more active against LAB and Listeria spp., and compared with the data given by Green et al. [22] for pediocin PD-1 by $P$. damnosus, it appears to be significantly more effective against Listeria. Pediocin SM-1 is not active against the Gram-negative Salmonella spp.

The antimicrobial activity against a wide range of Grampositive bacteria and the minimum inhibition concentrations of pediocin L50, produced by $P$. acidilactici L50, have been presented by Cintas et al. [103]. Its inhibitory spectrum was found to be broad, although resistant lactobacilli were found, and it was very effective against $L$. monocytogenes. The antimicrobial activity of pediocin PD1 against a wide range of bacteria has been discussed by Green et al. [22]. 
Table I: Inhibitory spectrum of pediocin SA-I produced by Pediococcus acidilactici NRRL B5627

\begin{tabular}{|c|c|c|c|c|}
\hline \multirow[t]{2}{*}{ Indicator organism } & \multicolumn{3}{|c|}{ Cultivation conditions } & \multirow[t]{2}{*}{ Sensitivity * } \\
\hline & Medium & Incubation temperature & Aeration & \\
\hline Bacillus cereus LMGI3569 & $\mathrm{BHI}$ & 30 & Aerobic & + \\
\hline Clostridium sporogenes NCTC533 & $\mathrm{RCM}$ & 37 & Anaerobic & +++ \\
\hline Clostridium thiaminolyticum ATCCI 5579 & $\mathrm{RCM}$ & 37 & Anaerobic & +++ \\
\hline Enterococcus faecalis NCTC8 I 76 & MRS & 37 & Microaerophilic & ++ \\
\hline Lactobacillus brevis ATCC8287 & MRS & 37 & Microaerophilic & +++ \\
\hline Lactobacillus bulgaricus LMG I355 I & MRS & 37 & Microaerophilic & +++ \\
\hline Lactobacillus casei ATCC344 & MRS & 37 & Microaerophilic & + \\
\hline Lactobacillus curvatus ATCC5 I 436 & MRS & 30 & Microaerophilic & ++ \\
\hline Lactobacillus jensenii ATCC25258 & MRS & 37 & Microaerophilic & + \\
\hline Lactobacillus plantarum CECT220 & MRS & 30 & Microaerophilic & + \\
\hline Lactobacillus plantarum NCAIM B 0 I I 33 & MRS & 30 & Microaerophilic & + \\
\hline Lactobacillus sakei CECT906T & MRS & 30 & Microaerophilic & + \\
\hline Lactococcus lactis LM0230 & MRS & 30 & Microaerophilic & + \\
\hline Lactococcus lactis ATCCI I454 & MRS & 30 & Microaerophilic & + \\
\hline Lactococcus lactis IL I 403 & MRS & 30 & Microaerophilic & + \\
\hline Lactococcus lactis spp. cremoris MCI363 & MRS & 30 & Microaerophilic & + \\
\hline Leuconostoc mesenteroides spp. cremATCCI 9254 & MRS & 25 & Microaerophilic & +++ \\
\hline Listeria inocua ATCC BAA-680D & $\mathrm{BHI}$ & 30 & Microaerophilic & +++ \\
\hline Listeria monocytogenes ATCC I 9 I I I & $\mathrm{BHI}$ & 30 & Microaerophilic & +++ \\
\hline Micrococcus flavus ATCC400 & NB & 30 & Aerobic & +++ \\
\hline Micrococcus luteus CECT24I & NB & 30 & Aerobic & +++ \\
\hline Pediococcus acidilactici ATCC25740 & MRS & 30 & Microaerophilic & ++ \\
\hline Pediococcus pentosaceus ATCC 33316 & MRS & 30 & Microaerophilic & ++ \\
\hline Pediococcus pentosaceus LMG I 3560 & MRS & 30 & Microaerophilic & ++ \\
\hline Pediococcus pentosaceus NRRL B I 4009 & MRS & 30 & Microaerophilic & ++ \\
\hline Salmonella enteritidis ATCCI3076 & SS & 25 & Microaerophilic & - \\
\hline Staphylococcus carnosus LMG I 3564 & $\mathrm{BHI}$ & 37 & Microaerophilic & ++ \\
\hline
\end{tabular}

$*+$, sensitivity to pediocin SA-I given at three degrees,,++++++

-, resistant to pediocin SA-I

Although there is high structural similarity in pediocins, and within the class IIa of bacteriocins, sensitivities of target-bacteria may vary markedly. There should be a number of reasons for this, as for example the existence of cell surface structures with which the bacteriocin interacts, or the composition of cell membrane, or the classical antibacterial assays which are not very sensitive, and many others. Further information on the subject can be found in the recent and important review by Drider et al. [89] on the "continuing story" of class IIa bacteriocins.

\section{Mode of action}

The cytoplasmic membrane of Gram-positive bacteria is the target of pediocins [1]. All the class IIa bacteriocins whose modes of action have been studied permealize the cytoplasmic membrane through pore formation by insertion of the C-terminal regions into the membrane [89]. However, the specific role of the YGNGV motif of the pediocins has not clarified yet. Pediocins are bactericidal to sensitive Gram-positive bacteria [5]. Being hydrophobic molecules, they destabilize the cytoplasmic membrane when they come in contact with it. This action includes loss of the permeability barrier and loss of the membrane potential, which, in strains that possess an autolytic system, result in cell lysis.

The mode of action of pediocin AcH/PA-1 has been studied by Bhunia et al. [110], Motlagh et al. [111] and Ray $[5,64]$. Loss of intacellular $\mathrm{K}^{+}$, entrance of lactose from the medium inside the cells and cell lysis of some strains, indicated the destabilization of the membrane functions by the pediocin. Pediocin AcH/PA-1 was found to bind to receptors on the cell surface of both sensitive and resistant cells to it [110]. Destabilization of the membrane occurred only in sensitive cells because of some types of conformation alterations which took place only to them and impaired the permeability of the membrane. The resistance of the producer strain $P$. acidilactici $\mathrm{H}$ to pediocin AcH/PA-1, is controlled by an immunity protein encoded by the specific immunity gene [5]. Gram-negative bacteria do not adsorb the pediocin and this may be the reason of their resistance. Injured, by sublethal stresses, Gram-negative bacteria became sensitive to pediocin. It was postulated that pediocin AcH/PA-1 enters the cells through the damaged outer membrane, comes in contact with the inner membrane and destabilizes its 
functions and kills the cells $[5,64]$. Spores also of Grampositive bacteria do not adsorb the pediocin AcH/PA-1 [5]. Following germination and outgrowth, the sensitive cells adsorb the pediocin and are killed.

More purified pediocins have been examined for their mode of action in the works of Green et al. [22] and Bauer et al. [54] for pediocin PD-1 produced by $P$. damnosus, and the works of Anastasiadou et al. [36,56] for pediocins SA1 from $P$. acidilactici and SM-1 from P. pentosaceus. Using the indicator bacterium Oenococcus oeni, Bauer et al. [54] concluded that pediocin PD-1 acts on its cytoplasmic membrane and the antimicrobial activity is due to the generation of pores in the membrane. The ability of pediocin PD-1 to form pores in sensitive cells of O. oeni, as observed by $\mathrm{K}^{+}$loss was found to be $\mathrm{pH}$ dependent and increased when the extracellular $\mathrm{pH}$ was reduced from 7.0 to 5.0. Although the rate of pediocin induced $\mathrm{K}^{+}$loss was the highest at $\mathrm{pH} 5.0$, the initial rate of $\mathrm{K}^{+}$loss was the highest at $\mathrm{pH}$ 6.0. This suggest that the $\mathrm{DpH}$ driving force contributes to the action of the pediocin, as it has been also observed with the lantibiotic nisin from $L$. lactis [112], and a synergistic effect between pediocin PD-1 and $\mathrm{pH}$ is possible. In the presence of $10 \mathrm{mM}$ gadolinium $\left(\mathrm{Gd}^{+}\right)$, pediocin PD-1 did not affect cells of O. oeni. This suggests that the mode of action of the pediocin relies on a net negatively charged cell surface. Following detailed investigations on the $\mathrm{K}^{+}$efflux and comparisons with nisin, Bauer et al. [54] proposed that cell death is a result of membrane disruption and a rather slow process of loss of metabolites rather than an immediate loss, as happens with nisin. Studies with treatment of sensitive O. oeni cells with cations, led to the postulation that pediocin PD-1 may also inhibit cell wall biosynthesis, which leads to cell lysis. Anastasiadou et al. [36,56] observed a bactericidal mode of action in studies with purified pediocins SA-1 and SM-1 and indicator cells of Micrococcus luteus at midlogarithmic phase of growth. The decrease in colony forming units of plated M. luteus from $10^{8}$ to 0 with 4 hours, was accompanied by unchanged turbidity at OD $600 \mathrm{~nm}$ (no cell lysis). Cell suspensions of treated cells were examined for the presence of DNA and for increase of protein levels and in both cases were negative. Similar were the findings with pediocin PD-1 and O. oeni cells, as reported by Green et al. [22].

All class IIa bacteriocins are believed to bind to a chiral receptor in cell membranes and create a pore that depolarizes the target cell. The exact nature of the bacteriocinreceptor interaction is not yet understood, but it appears to be mediated by the membrane bound proteins $\mathrm{mptC}$ and/or mptD [113]. In their most recent work, Derksen et al. [113] proceeded in synthesis of class IIa bacteriocins (pediocin PA-1 and leucocinA) mutants and analogues, to investigate the structure-function relationship and to obtain further information on the peptide-receptor complex. Their results were consistent with the idea that the selectivity and activity of class IIa bacteriocins is dependent on their entire sequence and the overall three-dimensional structure preferred in membranes.

The factors affecting the efficacy of the various pediocins against sensitive target-cells are less investigated. Bauer et al. [54] presented results that show the activity of pediocin PD-1 to be dependent on the growth temperature of the indicator bacterium O. oeni. This was attributed to membrane fluidity changes and alteration of its lipid and protein contents that affect the resistance of the membrane to pore formation. The authors stress the need for further studies on the efficacy of antimicrobial peptides in general, under a range of growth phases and conditions before making generalized conclusions. When food is in concern, it is important to distinguish among the various growth phases of the target-cells in order to assure effective control and preservation. In this respect, characteristic is the study by Todorov and Dicks [73] with the antimicrobial effect of pediocin ST18 on L. innocua F. Addition of bacteriocin containing cell-free filtrate (3200 AU/ml) to logarithmic-phase cells resulted in growth inhibition after 1 hour that completed in 2 hours. Addition of the same activity level of pediocin to stationary-phase cells of L. innocua resulted in no growth inhibition.

\section{Physicochemical and biochemical properties of pediocins}

The known pediocins from $P$. acidilactici, $P$. pentosaceus and $P$. damnosus strains are mostly small, hydrophobic proteins. Their bactericidal action is stable to heat treatment, sometimes even at sterilization temperatures, as well as to cold treatment, even at $-80^{\circ} \mathrm{C}$. Their activity is retained at a wide $\mathrm{pH}$ range. They are sensitive to most proteases. These characteristics are common in a number of pediocins as shown with pediocin AcH/PA-1 [5], pediocin ST18 [73], pediocin AcM [104], pediocin L50 [103], pediocin PD-1 [22], pediocin F [69], the pediocins produced by $P$. pentosceus Pep1 [72] and P. pentosaceus K23-2 [107].

Table 2 summarizes some of the properties of isolated pediocins, in the cases the particular characteristics were examined and allow comparisons. The obvious differences, as shown in Table 2, may result in differences in the way of action and may explain the differences found in the inhibitory spectra of various pediocins. In overall, it can be concluded that pediocins have important technological properties for being considered as mild antimicrobials and biopreservatives.

Pediocin AcH/PA-1 was the first to be studied with respect to its biochemical properties [5]. The recently isolated and characterized pediocin SA-1 from $P$. acidilactici NRRL 
Table 2: Effects of heat, $\mathrm{pH}$ and proteolytic enzyme treatments on the antimicrobial activity of various isolated pediocins

\begin{tabular}{|c|c|c|c|c|c|c|c|c|c|c|}
\hline \multicolumn{11}{|c|}{ Treatment* } \\
\hline \multicolumn{3}{|c|}{ Temperature } & \multicolumn{2}{|c|}{$\mathrm{pH}$} & \multicolumn{4}{|c|}{ Proteolytic enzymes } & \multirow[b]{2}{*}{ Proteinase $\mathrm{K}$} & \multirow[b]{2}{*}{ Reference } \\
\hline Pediocin & $100^{\circ} \mathrm{C} / 60 \mathrm{~min}$ & $121^{\circ} \mathrm{C} / 60 \mathrm{~min}$ & $2-10$ & $4-7$ & Pepsin & Papain & Trypsin & $\alpha$-chymotrypsin & & \\
\hline \multirow[t]{2}{*}{ SM-I } & + & + & & & - & - & - & - & - & Anastasiadou et al. 2008 \\
\hline & + & + & + & + & - & ND & ND & ND & - & \\
\hline \multirow[t]{2}{*}{ pK23-2 } & & & & + & & & & & & Shin et al. 2008 \\
\hline & & & + & & & & & & & \\
\hline SA-I & + & + & + & + & + & + & + & + & - & Anastasiadou et al. 2007 \\
\hline ACCEL & + & \pm & + & + & - & - & - & - & - & Wu et al. 2004 \\
\hline PD-I & + & + & + & + & + & + & + & + & - & Green et al. 1997 \\
\hline SJ-I & + & + & - & + & ND & - & - & - & - & Schved et al. 1993 \\
\hline N5p & + & + & - & + & ND & ND & ND & ND & ND & Strässer et al. 1995 \\
\hline $\mathrm{AcH}$ & + & + & + & + & ND & - & - & - & - & Bhunia et al. 1988 \\
\hline PA-I & + & \pm & + & + & - & - & ND & ND & ND & Gonzales and Kunka 1987 \\
\hline
\end{tabular}

$*+$, Activity; -, Absence of any activity; ND, not determined.

B5627 [36] was also found to be a very stable pediocin at various conditions. The purified pediocin SA-1 is heat stable for up to $60 \mathrm{~min}$ at $121^{\circ} \mathrm{C}$. Storage for 4 weeks at -80 , $-20,4$ and $30^{\circ} \mathrm{C}$ did not affect its antimicrobial activity. This was not impaired even following incubation at $30^{\circ} \mathrm{C}$ for 1 week at $\mathrm{pH}$ values ranging between 3.0 to 12.0 . No antimicrobial activity was detected however, after $30 \mathrm{~min}$ of incubation in buffers of pH 2.0, 13.0 and 14.0. Pediocin SA-1 was found to be resistant to treatment with trypsin, $\alpha$-chymotrypsin, pepsin and papain, but not to proteinase K. Pediocin SM-1 from P. pentosaceus SM-1 [56] was also found to be inactivated by the above enzymes. The purified pediocin ACCEL, produced by $P$. pentosaceus ACCEL [70], was inactivated by proteolytic treatment and remained stable with the narrower $\mathrm{pH}$ range of 2.0 to 6.0 and at lower temperatures of $<100^{\circ} \mathrm{C}$. However, more of $80 \%$ of its activity was remained even after $15 \mathrm{~min}$ of heating at $121{ }^{\circ} \mathrm{C}$, at $\mathrm{pH} 2.0-4.0$. The also recently isolated pediocin from $P$. pentosaceus K23-2 [107] was found to be very heat-stable, as its activity remained unchanged following $15 \mathrm{~min}$ of incubation at $121^{\circ} \mathrm{C}$.

Pediocins, as all class IIa bacteriocins, are essentially unstructured in water (have random coil structures) and assume a defined conformation only in hydrophobic environments or in solvents $[89,113,114]$. Various environmental factors, e.g. temperature, $\mathrm{pH}$ and others, affect their defined structure and their antimicrobial activity. Kaur et al. [114] studied the effects of temperature on antimicrobial activity and on structure of the C-terminal amphipathic $\alpha$ helix as a receptor-binding region. They reported that at elevated temperatures pediocin PA-1 maintains its overall structure, whereas peptides without a second C-terminal disulfide bond, such as sakacin $\mathrm{P}$, curvacin $A$, enterocin $P$, experience partial disruption of the helical section. Pediocin PA-1 and a chemically synthesized mutant of it, in which methionine was replaced by norleucine (for enhanced stability toward aerobic oxidation), were found to be equally active at different temperatures, whereas the peptides that lack the second disulfide bond in the C-terminal were 30-50 times less antimicrobially potent at $37^{\circ} \mathrm{C}$ than at $25^{\circ} \mathrm{C}$. The structural changes in the helical region observed (CD spectroscopy was employed) at elevated temperatures account for the loss of activity of these peptides. The presence of the C-terminal disulphide bond in pediocin PA-1 helps in maintaining the tertiary structure of the peptide at elevated temperatures, while in the absence of it the peptides experience a significant structural peprturbation in the amphipathic helix region (loss of the helical content). The hydrophobic residues of the C-terminal helical domain orient themshelves on one side of the helix, facilitating this way a specific interaction with the receptor protein (probably a region of the mannose specific PTS subunit IID) on the target cell. The study of Kaur et al. [114] showed that the $\alpha$ helix in the C-terminal of the pediocins is critical for activity and helped significantly in the understanding of the structure-function relationship.

\section{Applications and perspectives}

Biopreservation systems, such as bacteriocinogenic cultures and/or their bacteriocins, have received increasing attention in recent years [115]. Pure or mixed cultures of bacteriocin-producer lactic acid bacteria, including the pediococci, are marketed today as protective cultures against common food spoilage bacteria and pathogens. Application of such cultures may lead to improvements in food quality and sensory attributes through controlling adventitious flora and inducing cell lysis [116]. Although there are commercial enzymes that can be used to carry out cell lysis, their controlled application is difficult and they can be expensive, while bacteriocin-producer cultures can perform the process in a milder and less expensive way and with overall improvements of flavour and 
quality because of the growth of the cultures themselves and the production of other metabolites at the same time. Danisco have formulated a freeze-dried $P$. acidilactici culture, marketed as CHOOZIT ${ }^{\mathrm{TM}}$ Lyo. Flav 43, which is suggested for use in cheddar cheese and semi-hard cheeses as an adjunct that "accelerates and enhances strong and sweet flavour compounds, due to the production of bacteriocins".

The number of scientific publications on the use of bacteriocins for food preservation is currently steadily increasing. The subject is covered by recent excellent reviews, such as those by Deegan et al. [115] and Guinane et al. [116]. Although many bacteriocins exhibit significant antimicrobial and other technologically important qualities, the use of a bacteriocin alone in a food cannot ensure sufficient safety. Gram-negative bacteria do not represent target cells for bacteriocins as they are protected by an outer membrane. It is therefore necessary that bacteriocins are used in combination with other preservation methods (e.g. other antimicrobials, or organic acids) and according to Deegan et al. [115] it may emerge that industrially they will be applied as a final hurdle in a food system following others that already exist and eliminate the non-targets to bacteriocins pathogens and spoilers. Until recently, nisin was the only bacteriocin marketed as food biopreservative. Recently, a pediocin by $P$. acidilactici containing formulation is marketed under the commercial name Alta $2341^{\circledast}$. Although research results regarding the efficiency of bacteriocins as biopreservatives are remarkable and promising, there is substantial reluctance by the industry to commit financially in developing commercial bacteriocin preparations. This is because of the costly production (low production rates, unstable products and expensive downstream processing) and difficulties that can arise from legislation. The costly production can be counteracted by suitable bioprocessing strategies designed for increased yields and by genetic engineering approaches.

Genetic engineering has been applied with Pediococcus spp. and pediocins in studies of the physiology of the producer-microorganisms, the complex structure-function relationship and the specificity of the pediocins, or for improvements in utilization of certain substrates, e.g. lactose, or even the construction of hybrid bacteriocins with improved stability and other properties $[16,101,102,113,114,117,118]$. The most desired characteristic when a pediocin is to be used as a food additive is its stability in the complex environment of food. Several of the pediocin-like bacteriocins contain methionine residues whose sulfur atom may be oxidized, resulting in destabilization of the bacteriocin. Johnsen et al. [119] focused on the methionine residue of the pediocin PA-1 and constructed variants in which the Met13 residue was replaced by Ala, Leu, Ile, and Asp. Replacing the Met13 with the first three, protected the peptide from oxidation and had only minor effects on antimicrobial activity, while replacement by Asp resulted in a marked decrease in potency against all indicator strains used. Therefore, making pediocin PA-1 more stable by replacing the methionine with another hydrophobic residue and retaining its activity is an important step in developing pediocin PA-1 into a useful food additive.

Research in the topic of the genetic engineering of pediocins is rather limited. Continued research may lead to pediocins with increased stability and enhanced features, or extension of the antimicrobial spectrum to Gram-negative bacteria. The engineering strategies may yield characteristics that could be very rewarding from a food safety and an economic point of view, however, they can be counterproductive from the marketing point of view, since they will yield products-pediocins made by genetic engineering with all the associated consumer concerns.

Food application of pediocins can provide a good alternative means in protecting food against foodborne pathogens. As products of lactic acid bacteria, they provide natural means of preservation and can be accepted by the consumers in the way nisin became accepted. As the trend of consumption of minimal processed and preserved foods is increasing, use of pediocins by the food industry could offer solutions and provide alternatives of conventional preservation means. Being mild antimicrobials, pediocins are also expected in the future to find more applications in both human and veterinary medicine. The growing problem of bacterial resistance to antibiotics could be faced by using antibiotic complements of bacteriocins, as studies have shown for nisin [119-121].

\section{Competing interests}

The authors declare that they have no competing interests.

\section{Authors' contributions}

MP drafted the manuscript. SA contributed additional content throughout the article. All authors have read and approved the final manuscript.

\section{References}

I. Papagianni M: Ribosomally synthesized peptides with antimicrobial properties: biosynthesis, structure, function, and applications. Biotechnol Adv 2003, $21: 465-499$.

2. Garvie El: Genus Pediococcus claussen 1903. In Bergey's Manual of Systemic Bacteriology Sneath, PHA Volume 2. The Williams \& Wilkins Company, Baltimore, USA; 1986: 1075-1079.

3. Gherna R, Pienta P: American Type Culture Collection: Catalogue of Bacteria and Phages. 17th edition. American Type Culture Collection, Rockville, USA; 1989.

4. Kitahara K: Genus Pediococcus balcke 1884, 247. In Bergey's Manual of Determinative Bacteriology 8th edition. Edited by: Buchanan RE, Gibbons NE. The Williams \& Wilkins Company, Baltimore, USA; 1974:5।3-5I5.

5. Ray B: Pediococcus in Fermented Foods. In Food Biotechnology: Microorganisms Edited by: Hui $\mathrm{YH}$, Khachatourians G. Wiley-VCH, USA; 1995:745-795. 
6. Dallaglio F, Trovatelli LD, Sarra PG: DNA-DNA homology among representative strains of the genus Pediococcus. Zentbl Bakteriol Mikrobiol Hyg I98I, 2: I40-I50. I Abt Orig C

7. Collins MD, Williams AM, Wallbanks S: The phylogeny of Aerococcus and Pediococcus as determined by I6S rRNA sequence analysis: description of Tetragenococcus gen. nov. FEMS Microbiol Lett 1990, 70:255-262.

8. Schlegel HG: General Microbiology. In English translation 7th edition. Cambridge University Press, Cambridge, UK; 1993.

9. Atlas RM: Handbook of microbiological media. CRC Press. Boca Raton FL, USA; 2004.

10. Gasson MJ, DeVos WM, (editors): Genetics and biotechnology of lactic acid bacteria. Blackie Academic \& Professional, Glasgow, UK; 1994.

II. Wood BJB: Microbiology of Fermented Foods. Blackie A\&P London, UK; 1997.

12. Knorr D: Technological aspects related to microorganisms in functional foods. Trends Food Sci Technol 1998, 9:295-306.

13. Bhowmik T, Marth EH: Role of Micrococcus and Pediococcus species in cheese ripening: a review. J Dairy Sci 1990, 73:859-866.

14. Bhowmik T, Riesterer R, van Boekel MAJS, Marth EH: Characteristics of low-fat cheddar cheese made with added Micrococcus or Pediococcus species. Milchwissenschaft 1990, 45:230-235.

15. Reinbold GW, Reddy MS: Preparation of pizza cheese. US patent 4,085,228 1978 .

16. Caldwell SL, McMahon DJ, Oberg C], Broadbent JR: Development and characterization of lactose-positive Pediococcus species for milk fermentation. Appl Environ Microbiol 1996, 62:936-94।.

17. Nakagawa A, Kitahara K: Taxonomic studies on the genus Pediococcus. J Gen Microbiol 1959, 5:95-126.

18. Sakaguchi K: Studies on the activities of bacteria in soy sauce brewing. Part 3. Taxonomic studies on Pediococcus sojae nov. sp., the soy sauce lactic acid bacteria. Bull Agric Chem Soc Jpn 1958, 22:353-362

19. Kanbe C, Uchida K: Citrate metabolism by Pediococcus halophilus. Appl Environ Microbiol 1987, 53:1257-1262.

20. Priest FG: Gram-positive brewery bacteria. In Brewing Microbiology 2 nd edition. Edited by: Priest FG, Campbell I. Elsevier, London, UK; 1996.

21. Delves-Broughton J: Nisin and its uses as a food preservation. Food Technol 1990, 44: 100-II0.

22. Green G, Dicks LMT, Bruggeman G, Vandamme El, Chikindas ML Pediocin PD-I, a bactericidal antimicrobial peptide from Pediococcus damnosus NCFB 1832. J Appl Microbiol 1997, 83: $127-132$.

23. Mora D, Fortina MG, Parini C, Manachini PL: Identification of Pediococcus acidilactici and Pediococcus pentosaceus based on I6S rRNA and IdhD-targeted multiplex PCR analysis. FEMS Microbiol Lett 1997, I 5 I:231-236.

24. Mora D, Parini C, Fortina MG, Manachini PL: Discrimination among pediocin AcH/PA-I producer strains by comparison of ped $B$ and pedD amplified genes and multiplex PCR assay. Syst Appl Microbiol 1998, 2 I:454-460.

25. Mora D, Fortina MG, Parini C, Daffonchio D, Manachini PL: Genomic sub-populations within the species Pediococcus acidilactici detected multilocus typing analysis: relationships between pediocin AcH/PA-I producing and non-producing strains. Microbiology 2000, 146:2027-2038.

26. Jager K, Harlander S: Characterization of a bacteriocin from Pediococcus acidilactici PC and comparison of bacteriocinproducing strains using molecular typing procedures. Appl Microbiol Biotechnol 1992, 37:631-637.

27. Satokari R, Mattila-Sandholm T, Suihko ML: Identification of pediococci by ribotyping. I Appl Microbiol 2000, 88:260-265.

28. Barney M, Volgyi A, Navarro A, Ryder D: Riboprinting and I6S rRNA gene sequencing for identification of brewery Pediococcus isolates. Appl Environ Microbiol 2002, 67:553-560.

29. Omar NB, Ampe F, Raimbault M, Guyot JP, Tailliez P: Molecular diversity of lactic acid bacteria from cassava sour starch (Colombia). Syst Appl Microbiol 2000, 23:285-29I.

30. Simpson PJ, Stanton C, Fitzerald GF, Ross RP: Genomic diversity within the genus Pediococcus as revealed by randomly amplified polymorphic DNA PCR and pulsed-field gel electrophoresis. Appl Environ Microbiol 2002, 68:765-771.

31. Bhunia AK, Johnson MG: Monoclonal antibody colony immunoblot method specific for isolation of Pediococcus acidilactici from foods and correlation with pediocin (bacteriocin) production. Appl Environ Microbiol 1992, 58:23I 5-2320.

32. Motlagh AM, Bhunia AK, Szostek F, Hansen T, Johnson MC, Ray B: Nucleotide and amino acid sequence of pap-gene (pediocin AcH production) in Pediococcus acidilactici H. Lett Appl Microbiol 1992, 15:45-48.

33. Johnson MC, Hanlin MB, Ray B: Low pH and lactate are necessary for conversion of prepediocin to pediocin AcH in Pediococcus acidilactici H. In Annu Meeting 1992, New Orleans, LA, May 26-30. Abstr. 08I American Society for Microbiology, Washington DC, USA.

34. Henderson JT, Chopco AL, van Wassenaar PD: Purification and primary structure of pediocin PA-I produced by Pediococcus acidilactici PACI 0. Arch Biochem Biophys 199I, 295:5-12.

35. Lozano JCN, Meyer JN, Sletten K, Pelaz C, Ness IF: Purification and amino acid sequence of a bacteriocin produced by Pediococcus acidilactici. J Gen Microbiol 1992, I38:1985-1990.

36. Anastasiadou S, Papagianni M, Filiousis G, Ambrosiadis I, Koidis P. Pediocin SA-I, an antimicrobial peptide from Pediococcus acidilactici NRRL B5627: Production conditions, purification and characterization. Biores Technol 2008, 99:5384-5390.

37. Sire JM, Donnio PY, Mesnard R, Pouëdras P, Avril JL: Septicemia and hepatic abscess caused by Pediococcus acidilactici. Eur J Clin Microbiol Infect Dis 1992, I I:623-625.

38. Dobrogosz WJ, Stone RW: Oxidative metabolism in Pediococcus pentosaceus. I. Role of oxygen and catalase. J Bacteriol I 962 84:716-723

39. Delwiche EA: Catalase of Pediococcus cerevisiae. J Bacteriol I96I, 8I:4|6-4|8.

40. Raccach M: Pediococci and biotechnology. Crit Rev Microbiol I987, 14:29|-309.

4I. Kimura H, Nagano R, Matsusaki H, Sonomoto K, Ishizaki A: A bacteriocin of strain Pediococcus sp. ISK-I isolated from Nukadoko, bed of fermented rice bran. Biosci Biotechnol Biochem 1997. 61:1049-105I.

42. Makarova K, Slesarev A, Wolf $Y$, Sorokin A, Mirkin B, Koonin E, Pavolv A, Pavlova N, Karamychev V, Polouchine N, Shakhova V, Grigoriev I, Lou Y, Rohksar D, Lucas S, Huang K, Goldstein DM, Hawkins $\mathrm{T}$, Plengvidhya $\mathrm{V}$ : Comparative genomics of the lactic acid bacteria. Proc Natl Acad Sci USA 2006, I03:156I I-156I6.

43. Entrez Genome Project: Pediococcus pentosaceus ATCC 25745 [http:/ /www.ncbi.nlm.nih.gov]. I May 2007.

44. Site [http://www.membranetransport.org]

45. Corcoran GD, Gibbons N, Mulvihill TE: Septicemia caused by Pediococcus pentosaceus: a new opportunistic pathogen. J Infect I99I, 23:179-I82.

46. Barton LL, Ryder ED, Cohen RW: Bacteremic Infection with Pediococcus: vancomycin-resistant opportunist. Pediatrics 200I, 107:775-776

47. Collins MD, Rodrigues UM, Ash C, Aguirre M, Farrow JAE, MartinezMurcia A: Phylogenic analysis of the genus Lactobacillus and related lactic acid bacteria determined by reverse transcriptase sequencing of I6S rRNA. FEMS Microbiol Lett I99I, 77:5-12

48. Suzuki K, Ozaki K, Yamashita Y: Comparative analysis of conserved genetic markers and adjacent DNA regions identified in beer-spoilage lactic acid bacteria. Lett Appl Microbiol 2004, 39:240-245.

49. Suzuki K, Sami M, lijima K, Ozaki K, Yamashita Y: Characterization of horA and its flanking regions of Pediococcus damnosus ABBC478 and development of more specific and sensitive horA PCR method. Lett Appl Microbiol 2006, 42:392-399.

50. Calmin G, Lefort L, Belbahri L: Multi-loci sequence typing (MLST) for two lacto-acid bacteria (LAB) species: Pediococcus parvulus and $P$. damnosus. Mol Biotechnol 2008, 40: I70-I79.

5I. Li A, Kong F: Synthesis of an alpha-linked dimmer of the trisaccharide repeating unit of the exopolysaccharide produced by Pediococcus damnosus 2.6. Carbohydr Res 2004, 20:2499-2506.

52. Skytta E, Haikara A, Mattila-Sandholm T: Production and characterization of antibacterial compounds produced by Pediococcus damnosus and Pediococcus pentosaceus. J Appl Bacteriol 1993, 74:134-142.

53. Nel HA, Bauer R, Vandamme El, Dicks LM: Growth optimization of Pediococcus damnosus NCFB I 832 and the influence of $\mathrm{pH}$ and nutrients on the production of pediocin PD-I. J Appl Microbiol 200I, $91:$ II31-II38. 
54. Bauer R, Chikindas ML, Dicks LMT: Purification, partial amino acid sequence and mode of action of pediocin PD-I, a bacteriocin produced by Pediococcus damnosus NCFB I832. Int J Food Microbiol 2005, 10 I: 17-27.

55. Biswas SR, Ray P, Johnson MC, Ray B: Influence of growth conditions on the production of a bacteriocin, pediocin $\mathrm{AcH}$, by Pediococcus acidilactici H. Appl Environ Microbiol 1991, 57:1265-1267.

56. Anastasiadou S, Papagianni M, Filiousis G, Ambrosiadis I, Koidis P: Growth and metabolism of a meat isolated strain of Pediococcus pentosaceus in submerged fermentation. Purification, characterization and properties of the produced pediocin SM-I. Enzyme MicrobTechnol 2008, 43:448-454.

57. Mundt JR, Beattie WG, Wieland FR: Pediococci residing in plants. J Bacteriol 1969, 98:938-942.

58. Vazquez JA, Gonzalez MP, Murado MA: Substrate inhibition of Pediococcus acidilactici by glucose on a waste medium. Simulations and experimental results. Lett Appl Microbiol 2003, 37:365-369.

59. Kim WJ, Ray B, Johnson MC: Plasmid transfers by conjugation and electroporation in Pediococcus acidilactici. J Appl Bacterio 1992, 72:201-207.

60. Altay G, Bozoglu F, Ray B: Efficiency of gene transfer by conjugation and electroporation in lactococci and pediococci. Food Microbiol 1994, I I:265-270.

61. Caldwell S, Hutkins RW, McMahon DJ, Oberg CJ, Broadbent JR: Lactose and galactose uptake by genetically engineered Pediococcus species. Appl Microbiol Biotechnol 1998, 49:3I5-320.

62. Barthelmebs L, Lecomte B, Divies C, Cavin JF: Inducible metabolism of phenolic acids in Pediococcus pentosaceus is encoded by an autoregulated operon which involves a new class of negative transcriptional regulator. J Bacteriol 2000, 182:6724-6731.

63. Mora D, Musacchio F, Fortina MG, Senini L, Manachini PL: Autolytic activity and pediocin-induced lysis in Pediococcus acidilactici and Pediococcus pentosaceus strains. J Appl Microbiol 2003, 94:56I-570.

64. Ray B: Pediocin(s) of Pediococcus acidilactici as a food biopreservative. In Food biopreservatives of microbial origin Edited by: Ray B, Daeschel M. CRC Press, Boca Raton FL, USA; 1992.

65. Anastasiadou S, Papagianni M, Ambrosiadis I, Koidis P: Rapid quantifiable assessment of nutritional parameters influencing pediocin production by Pediococcus acidilactici NRRL B5627. Biores Technol 2008, 99:6646-6650.

66. Cabo ML, Murado MA, Gonzales MP, Pastoriza L: Effects of aeration and $\mathrm{pH}$ gradient on nisin production. A mathematical model. Enzyme Microb Technol 200I, 29:264-273.

67. Amiali MN, Lacroix C, Simard RE: High nisin Z production by Lactococcus lactis UL7 19 in whey permeate with aeration. World J Microbiol Biotechnol 1998, 14:887-894.

68. De Vuyst L, Callewaert R, Crabbe K: Primary metabolite kinetics of bacteriocin biosynthesis by Lactobacillus amylovorus and evidence for stimulation of bacteriocin production under unfavourable growth conditions. Microbiology 1996, I 42:817-27.

69. Osmanagaoglou O, Gunduz U, Beyatli Y, Cokmus C: Purification and characterization of pediocin $F$, a bacteriocin produced by Pediococcus acidilactici F. TrJ of Biol 1998, 22:217-228.

70. Wu CW, Yin LJ, Jiang ST: Purification and characterization of bacteriocin from Pediococcus pentosaceus ACCEL. J Agr Food Chem 2004, 52: I|46-II5I.

71. Yin LJ, Wu CW, jiang ST: Bacteriocins from Pediococcus pentosaceus L and S from pork meat. J Agr Food Chem 2003, 5I:I07I-I076.

72. Osmanagaoglou $O$, Beyatli Y, Gunduz U: Isolation and characterization of pediocin producing Pediococcus pentosaceus PepI from vacuum-packed sausages. Turk J Biol 200I, 25: I33-143.

73. Todorov SD, Dicks LMT: Pediocin STI 8, an antilisterial bacteriocin produced by Pediococcus pentosaceus STI 8 isolated from boza, a traditional cereal beverage from Bulgaria. Process Biochem 2005, 40:365-370.

74. Guerra NP, Pastrana L: Dynamics of pediocin biosynthesis in batch fermentation on whey. Electron J Environ Agric Food Chem 2002, I:96-106

75. Guerra NP, Pastrana L: Modelling the influence of $\mathbf{p H}$ on the kinetics of both nisin and pediocin production and character- ization of their functional properties. Process Biochem 2002, 37:1005-1015.

76. Guerra NP, Pastrana L: Influence of pH drop on both nisin and pediocin production by Lactococcus lactis and Pediococcus acidilactici. Lett Appl Microbiol 2003, 37:5 I-55.

77. Vazquez JA, Gonzalez MP, Murado MA: Nisin and pediocin production by Lactococcus lactis and Pediococcus acidilactici using waste protein sources from octopus. Electron J Environ Agric Food Chem 2004, 3(2):

78. Nel HA, Vandamme EJ, Dicks LMT: Growth optimization of Pediococcus damnosus NCFB 1832 and the influence of $\mathrm{pH}$ and nutrients on the production of pediocin PD-I. J Appl Microbiol 200I, 9 I: I I3I-II38.

79. Guerra NP, Pastrana L: Nisin and pediocin production on mussel-processing waste supplemented with glucose and five nitrogen sources. Lett Appl Microbiol 2002, 34: I I 4-I I8.

80. Vazquez JA, Gonzalez MP, Murado MA: Peptones from autohydrolysed fish viscera for nisin and pediocin production. J Biotechnol 2004, I I 2:299-3 II.

8I. Guerra NP, Bernardez PF, Agrasar AT, Macias CL, Pastrana L: Fedbatch pediocin production by Pediococcus acidilactici NRRLB5627 on whey. Biotechnol Appl Biochem 2005, 42:17-23.

82. Guerra NP, Agrasar AT, Macias CL, Pastrana L: Modelling the fedbatch production of pediocin using mussel processing wastes. Process Biochem 2005, 40:1071-1083.

83. Guerra NP, Bernardez PF, Pastrana L: Modelling the stress inducing biphasic growth and pediocin production by Pediococcus acidilactici NRRL-B5627 in re-alkalized fed-batch cultures. Biochem Eng J 2008, 40:465-472.

84. Cho HY, Yousef AE, Yang ST: Continuous production of pediocin by immobilized Pediococcus acidilactici PO2 in a packedbed bioreactor. Appl Microbiol Biotechnol 1996, 45:589-594.

85. Liao CC, Yousef AE, Richter ER, Chism GW: Pedioccus acidilactici PO2 bacteriocin production in whey permeate and inhibition of Listeria monocytogenes in foods. J Food Sci 1993, 58:430-434.

86. Huang J, Lacroix C, Daba H, Simard RE: Pediocin production and plasmid stability during continuous free and immobilized cell cultures of Pediococcus acidilactici UL5. J Appl Bacteriol 1996, 80:635-644.

87. Naghmouchi K, Fliss I, Drider D, Lacroix C: Pediocin PA-I production during repeated-cycle batch culture of immobilized Pediococcus acidilactici UL5 cells. J Biosci Bioeng 2008, 105:513-517.

88. Vazquez Alvarez JA, Gonzalez MP, Murado MA: Pediocin production by Pediococcus acidilactici in solid state culture on a waste medium: Process simulation and experimental results. Biotechnol Bioeng 2004, 85:676-682.

89. Drider D, Fimland G, Hechard Y, McMullen LM, Prevost H: The continuing story of class Ila bacteriocins. Microbiol Mol Biol Rev 2006, 70:564-582.

90. Graham DC, McKay LL: Plasmid DNA in strains of Pediococcus cerevisiae and Pediococcus pentosaceus. Appl Environ Microbiol 1985, 50:532-534.

91. Daeschel MA, Klaenhammer TR: Association of a 13.6 MDal plasmid in Pediococcus pentosaceus with bacteriocin activity. Appl Environ Microbiol 1985, 50:1538-I54I.

92. Hoover DG, Walsh PM, Kolaetis KM, Daly MM: A bacteriocin produced by Pediococcus species associated with a $5.5 \mathrm{kDal}$ plasmid. J Food Prot 1988, 5 I:29-31.

93. Gonzalez CF, Kunka BS: Plasmid-associated bacteriocin production and sucrose fermentation in Pediococcus acidilactici. Appl Environ Microbiol 1987, 53:2534-2538.

94. Ray SK, Johnson MC, Ray B: Bacteriocin plasmids in Pediococcus acidilactici. J Ind Microbiol 1989, 4:|63-I7I.

95. Ennahar S, Sashihara T, Sonomoto K, Ishizaki A: Class Ila bacteriocins: biosynthesis, structure and activity. FEMS Microbiol Rev 2000, 24:85-106.

96. Miller KW, Schamber R, Osmanagaoglou O, Ray B: Isolation and characterization of pediocin AcH chimeric protein mutants with altered bactericidal activity. Appl Environ Microbiol 1998, 64:1997-2005.

97. Quadri LE, Yan LZ, Stiles ME, Vederas JC: Effect of amino acid substitutions on the activity of carnobacteriocin B2. Overproduction of the antimicrobial peptide, its engineered variables 
and its precursor in Escherichia coli. J Biol Chem 1997, 272:3384-3388.

98. Chen $Y$, Ludescher RD, Montville TJ: Electrostatic interactions but not the YGNGV consensus motif, govern the binding of pediocin PA-I and its fragments to phospholipids vesicles. Appl Environ Microbiol 1997, 63:4770-4777.

99. Kazazic M, Nissen-Meyer J, Fimland G: Mutational analysis of the role of charged residues in target-cell binding, potency and specificity of the pediocin-like bacteriocin sakacin P. Microbiology 2002, I 48:2019-2027.

100. Uteng M, Hauge HH, Markwick PR, Fimland G, Mantzilas D, NissenMeyer J, Muhle-Goll C: Three-dimensional structure in lipid micelles of the pediocin-like antimicrobial peptide sakacin $\mathbf{P}$ and a sakacin $P$ variant that is structurally stabilized by an inserted C-terminal disulphide bridge. Biochemistry 2003, 42:1|4|7-|| 426.

10I. Fimland G, Blingsmo OR, Sletten K, Jung G, Nes IF, Nissen-Meyer J: New biologically active hybrid bacteriocins constructed by combining regions from various pediocin-like bacteriocins: the C-terminal region is important for determining specificity. Appl Environ Microbiol 1996, 62:3313-33I8.

102. Fimland G, Jack R, Jung G, Jung G, Nes IF, Nissen-Meyer J: The bactericidal activity of pediocin PA-I is specifically inhibited by a 15-mer fragment that spans the bacteriocin from the center toward the C terminus. Appl Environ Microbiol 1998, 64:5057-5060

103. Cintas LM, Rodriguez JM, Fernandez MF, Sletten K, Nes IF, Hernandez $\mathrm{PE}$, Holo $\mathrm{H}$ : Isolation and characterization of pediocin L50, a new bacteriocin from Pediococcus acidilactici with a broad inhibitory spectrum. Appl Environ Microbiol 1995, 61:2643-2648.

104. Elegado FB, Kin W], Kwon DY: Rapid purification, partial characterization, and antimicrobial spectrum of the bacteriocin, pediocin AcM, from Pediococcus acidilactici M. Int J Food Microbiol 1997, 37:I-II.

105. Schved F, Lalazar Y, Henis Y, Juven BJ: Purification, partial characterization and plasmid-linkage of pediocin SJ-I, a bacteriocin produced by Pediococcus acidilactici. J Appl Bacteriol 1993, 74:67-77.

106. Strässer de Saad AM, Pasteris SE, Manca de Nadra MC: Production and stability of pediocin N5p in grape juice medium. J Appl Bacteriol 1995, 78:473-476.

107. Shin MS, Han SK, Ryu JS, Kim KS, Lee WK: Isolation and partial characterization of a bacteriocin produced by Pediococcus. pentosaceus K23-2 isolated from kimchi. J Appl Microbiol 2008 , 105:331-339.

108. Eijsink VG, Sheie M, Middelhoven PH, Brurberg MB, Nes IF: Comparative studies of class Ila bacteriocins of lactic acid bacteria. Appl Environ Microbiol 1998, 64:3275-328।.

109. Fimland G, Johnsen L, Axelsson L, Brurberg MB, Nes IF, Eijsink VGH, Nissen-Meyer J: A C-terminal disulfide bridge in pediocin-like bacteriocins renders bacteriocin activity less temperature dependent and is a major determinant of the antimicrobial spectrum. J Bacteriol 2000, 182:2643-2648.

I I0. Bhunia AK, Johnson MC, Ray B, Kalchayanad N: Mode of action of pediocin AcH from Pediococcus acidilactici $\mathrm{H}$ on sensitive bacterial strains. J Appl Bacteriol 199I, 70:23-25.

III. Motlagh AM, Johnson MC, Ray B: Viability loss of food borne pathogens by starter culture metabolites. J Food Prot 1991, 54:873-878.

I 12. Moll GN, Konings WN, Driessen AJM: Bacteriocins: mechanism of membrane insertion and pore formation. Antonie van Leeuwenhoek 1999, 76: 185-198.

1 13. Derksen DJ, Boudreau MA, Vederas JC: Hydrophobic interactions as substitutes for a conserved disulfide linkage in the type Ila bacteriocins, leucocin A and pediocin PA-I. Chem Bio Chem 2008, 9:1898-1901.

114. Kaur K, Andrew LC, Wishart DS, Vederas JC: Dynamic relationships among type Ila bacteriocins: temperature effects on antimicrobial activity and on structure of the C-terminal amphipathic $\alpha$ helix as a receptor-binding region. Biochemistry 2004, 43:9009-9020.

115. Deegan LH, Cotter PD, Hill C, Ross P: Bacteriocins: biological tools for bio-preservation and shelf-life extension. Int Dairy J 2006, 16:1058-107|.
116. Bhowmik T, Marth EH: $\beta$-galactosidase of Pediococcus species: induction, purification and partial characterization. Appl Microbiol Biotechnol 1990, 33:317-323.

117. Guinane CM, Cotter PD, Hill C, Ross RP: Microbial solutions to microbial problems: Lactococcal bacteriocins for the control of undesirable biota in food. / Appl Microbiol 2005, 98:|3|6-|325

I I8. Somkuti GA, Steiberg DH: Pediocin production by recombinant lactic acid bacteria. Biotechnol Lett 2003, 25:473-477.

119. Brumfitt W, Salton MRJ, Hamilton-Miller JMT: Nisin alone and combined with peptidoglycan-moduling antibiotics: activity against methicillin-resistant Staphylococcus aureus and vancomycin-resistant enterococci. J Anticrobiol Chemother 2002, 50:73I-734.

120. Giacometti A, Cirioni O, Barchiesi F, Fortuna M, Scalise G: In-vitro activity of cationic peptides alone and in combination with clinically used antimicrobial agents against Pseudomonas aeruginosa. J Anticrobiol Chemother 1999, 44:64I-645.

I2I. Wu J, Hu S, Cao L: Therapeutic effect of nisin Z on subclinical mastitis in lactating Cows. Antimicrob Agents Chemother 2007, 5I:3|3|-3|35.

Publish with Bio Med Central and every scientist can read your work free of charge

"BioMed Central will be the most significant development for disseminating the results of biomedical research in our lifetime. "

Sir Paul Nurse, Cancer Research UK

Your research papers will be:

- available free of charge to the entire biomedical community

- peer reviewed and published immediately upon acceptance

- cited in PubMed and archived on PubMed Central

- yours - you keep the copyright 